\title{
Patterns of Malignant Lymphoma among Admitted Patients in Al Gamhoria Hospital, Aden, Yemen
}

\author{
AHMED SALEH OMER AL-GEFRI, M.D.; BALQIS AL-SAYEED ABDULLA EBRAHIM, M.D. and \\ AHMED MUTHANNA NASSER ALBISHI, M.D.
}

The Department of Internal Medicine, Faculty of Medicine, Aden University, Yemen

\begin{abstract}
Background: Carcinoma has great prevalence among world population. World Health Organization (WHO) classification of malignant lymphoma has become popular since its introduction in 2001 and has been applied to the classification of malignant lymphoma in different countries around the world.
\end{abstract}

Aim of Study: This study was aimed to assess the prevalence of malignant lymphoma among admitted patients to AlGamhoria Teaching Hospital Aden, Yemen in the period between 2010-2014.

Methods: A retrospective descriptive study covering registered cases of lymphoma was applied over the period 2010-2014. Patient's registry data wascollecting from AlGamhoria Teaching Hospital Medical Registries Department. The following variables were studied included: Age, gender, tumor site, malignant lymphomas type according histopathology and residency.

Results: Both types of lymphoma were having convergent distribution. Most age groups affected were among 30-39 years in non-Hodgkin lymphoma, while in Hodgkin's lymphoma the predominant age group were among 20-29. Male being highest $(57.1 \%)$ than female $(42.9 \%)$. The mixed cellularity type was common representing $42.3 \%$ in Hodgkin's lymphoma. The nodular lymphoma was $54.7 \%$ while in the extra nodular lymphoma; the gastrointestinal was common representing $50 \%$. Most of the registered cases were from Aden Governorate where the hospital is located.

Conclusion: Male gender associated with high percentage, the middle age group and mixed cellularity were the predominant in Hodgkin's lymphoma. The gastrointestinal manifestation in extra nodular lymphoma was highly prevalent.

Key Words: Lymphoma-Malignant-Aden.

\section{Introduction}

MALIGNANT Lymphomas (ML) are heterogeneous group of diseases with differences in epidemiology, histology and prognosis [1]. The strongest

Correspondence to: Dr. Ahmed Saleh Omer Al-Gefri, The Department of Internal Medicine, Faculty of Medicine, Aden University, Yemen known risk factor is severe immunodeficiency, but the etiologies of most lymphomas remain unknown [ 2]. Other factors possibly associated include a variety of medical conditions (e.g., autoimmune diseases), infections (e.g., hepatitis $\mathrm{C}$ virus), occupations (e.g., farming), occupational and environmental risk factors (e.g., polychlorinated biphenyls, pesticides, solvents, hair dyes), and inherited genetic variations, all with moderate to weak strength of association or inconsistency in the literature [ 3,4]. Although the etiology of lymphoma is not yet completely understood, there are a few wellestablished risk factors of lymphoma such as aging, family history, and various infections. Aging is found to be the leading risk factor of lymphoma with higher incidence and mortality rates in older individuals [5]. Male sex have higher incidence rate of Hodgkin's disease (HL), Non-Hodgkin's Lymphoma (NHL) and Burkett's lymphoma with a ratio 1.5:1 [6]. According to age, it was documented that the mean age 32 years; and the first peak is in the age group 20-30 years and the second peak is in the age group 50-70 years [7].

Lymphoma is one of the most common threating life carcinoma which has great prevalence among world population [8]. World Health Organization ( WHO) classification of ML has become popular since its introduction in 2001 and has been applied to the classification of ML in different countries around the world. Different studies from America, Europe, Jordan, Iran, Japan, China, India, Iraq have revealed that the relative proportion of various ML according to WHO classification differ with geographical regions [9-11]. According to the Middle East Cancer Consortium in Egypt, the NHLs agestandardized incidence rates are $(16.3 / 100000$ person). This very high incidence makes NHL the third most common cancer in Egyptian men and the second most common cancer in women as reported by the National Cancer Institute, account- 
ing for $10.9 \%$ of all cancers in Egypt diagnosed every year [12]. The highest NHL incidence rates are seen in North America, Europe, Oceania, and some African countries, whereas the highest mortality rates are observed in New Zealand, Israel and Canada. These geographical variations may be related to differences in demographic, environmental and other factors [13]. In India, the NHL of lymphoma forms the higher number $(76.3 \%)$ then HL cases $(23.7 \%)$ of all cancers in many general hospitals [14]. Among the lymphomas $35-43 \%$ was $\mathrm{HL}$ and the rest of patients were NHL. It is more likely to be related with past history of glandular fever but no causal link to Epstein-Barr virus proven. It have been noticed that the lymphoma is one of the most common and frequent malignant tumor in South Eastern of Yemen, [15] which was a motivated factor for this study and was conducted with the principal objective of contributing to the study the prevalence of malignant lymphoma in Yemen.

\section{Patients and Methods}

\section{Study design and setting:}

This is a retrospective descriptive study conducted at Al-Gamhoria Teaching Hospital from 2010 to 2014.

\section{Sampling method:}

We reviewed a total of 105 files diagnosed with malignant lymphoma in the Medical Registries Department of Al-Gamhoria Teaching Hospital, Aden, Yemen from 2010 to 2014. Were data of all cases extracted from medical records included age, gender, tumor site, type of lymphoma, histopathology, stages and residency.

\section{Inclusion criteria:}

All the files that meet the requirements of the study and were filled appropriately were included in our study.

\section{Exclusion criteria:}

Files with in appropriate filling of the study variables were excluded from the study.

\section{Data analysis:}

Statistical analysis using software Statistical Package for Social Sciences (SPSS) version 22.0 was used and the results were shown in simple frequency percentage.

\section{Ethical clearance:}

Permission to conduct the study was obtained from the director of the hospital after approval of the Ethical Committee.

\section{Results and Discussion}

Lymphomas including both HL and NHL were the second most common malignancy in Aden representing $12 \%$ of all the cases registered and is considered as the first common malignancy among males. The median age of HL and NHL was 29.5 years. According to the registered data from 2010 to 2014, it was observed that the trend of lymphoma was increasing tremendously throughout each year ( Table 1). This could be explained by the improvement in the diagnostic procedures and the methods of discovering new cases, but at the same time it is necessary to search for the etiological factors in Yemen environment.

Table (1): Registered Lymphomas by average annual cases ( 2010-2014)

\begin{tabular}{lc}
\hline Years & Average no. of cases \\
\hline 2010 & 0 \\
2011 & 16 \\
2012 & 19 \\
2013 & 30 \\
2014 & 40 \\
\hline
\end{tabular}

Table (2) showed the frequency of cases according to gender of the registered cases during 20102014 and the type of lymphomas. Males were higher $(57.1 \%)$ than females (42.8\%). In HL, study showed approximately duplication of male to the female cases while in NHL the male to female percentage showed slight dominance. A study reported that lymphoma cases were exposed to pesticides during their life and females were affected more than males [16]. These data are in agreement with those reported by Akhtar et al., when found that, male to female ratio 1.6:1 and male preponderance was present [17].

Table (2): Hodgkin and non-Hodgkin lymphomas frequency by gender.

\begin{tabular}{lrrrrrr}
\hline \multirow{2}{*}{ Gender } & \multicolumn{2}{c}{ NHL } & \multicolumn{2}{c}{ HL } & \multicolumn{2}{c}{ Total } \\
\cline { 2 - 7 } & No. & $\%$ & No. & $\%$ & No. & $\%$ \\
\hline Males & 27 & 50.9 & 33 & 63.5 & 60 & 57.1 \\
Females & 26 & 49.0 & 19 & 36.5 & 45 & 42.9 \\
\hline Total & 53 & 50.5 & 52 & 49.5 & 105 & 100 \\
\hline
\end{tabular}

The age group most affected in all types of lymphomas was (30-39) years followed by (0-19) years in NHL and by 20-29 in HL (Table 3). The prevalence of NHL cases were few and differs from another, reported by Catherine et al., in which the disease was more common in the elderly and approximately half of cases were seen above the age of 65 [18]. 
Table (3): Distribution of lymphomas according to age group.

\begin{tabular}{llllccc}
\hline $\begin{array}{l}\text { Age group } \\
\text { years) }\end{array}$ & \multicolumn{2}{c}{ NHL } & \multicolumn{2}{c}{ HL } & \multicolumn{2}{c}{ Total } \\
\cline { 2 - 7 } & No. & $\%$ & No. & $\%$ & No. & $\%$ \\
\hline $0-19$ & 14 & 26.4 & 10 & 19.2 & 24 & 22.9 \\
$20-29$ & 8 & 15.1 & 11 & 21.2 & 19 & 18.1 \\
$30-39$ & 17 & 32.1 & 10 & 19.2 & 27 & 25.7 \\
$40-49$ & 7 & 13.2 & 3 & 58 & 10 & 9.5 \\
$50-59$ & 2 & 3.8 & 8 & 15.4 & 10 & 9.5 \\
60 \& more & 5 & 9.4 & 10 & 19.2 & 15 & 14.3 \\
\hline Total & 53 & 50.5 & 52 & 49.5 & 105 & 100 \\
\hline
\end{tabular}

As showed in (Table 4), the NHL was more frequent in males $(50.9 \%)$ than females $(49.1 \%)$. The peak of NHL cases was observed among the age group (30-39) years representing 32\%. Among males the percentage was similar among the age group 0-19 and 30-39 groups. NHL is more frequent in both gender and common through the second and third decades of life as expected by Satish and Richard [19].

Table (4): Distribution of NHL by gender and age group.

\begin{tabular}{lcccccc}
\hline $\begin{array}{l}\text { Age group } \\
\text { (years) }\end{array}$ & \multicolumn{2}{c}{ Male } & \multicolumn{2}{c}{ Female } & \multicolumn{2}{c}{ Total } \\
\cline { 2 - 7 } & No & $\%$ & No & $\%$ & No & $\%$ \\
\hline $0-19$ & 9 & 33.3 & 5 & 19.2 & 14 & 26.4 \\
$20-29$ & 5 & 18.5 & 3 & 11.5 & 8 & 15.1 \\
$30-39$ & 9 & 33.3 & 8 & 30.7 & 17 & 32.1 \\
$40-49$ & & 0.0 & 7 & 26.9 & 7 & 13.2 \\
$50-59$ & 1 & 3.7 & 1 & 3.8 & 2 & 3.7 \\
60 and more & 3 & 11.1 & 2 & 7.7 & 5 & 9.5 \\
\hline Total & 27 & 50.9 & 26 & 49.1 & 53 & 100 \\
\hline
\end{tabular}

Table (5): Distribution of HL by gender and age group.

\begin{tabular}{lrccccc}
\hline \multirow{2}{*}{ Age group } & \multicolumn{2}{c}{ Male } & \multicolumn{2}{c}{ Female } & \multicolumn{2}{c}{ Total } \\
\cline { 2 - 7 } & No & $\%$ & No & $\%$ & No & $\%$ \\
\hline $0-19$ & 6 & 18.18 & 4 & 21.00 & 10 & 19.23 \\
$20-29$ & 6 & 18.18 & 5 & 26.30 & 11 & 21.15 \\
$30-39$ & 8 & 24.24 & 2 & 10.50 & 10 & 19.23 \\
$40-49$ & 2 & 6.06 & 1 & 5.26 & 3 & 5.77 \\
$50-59$ & 4 & 12.12 & 4 & 21.00 & 8 & 15.38 \\
$60 \&$ above & 7 & 21.21 & 3 & 15.70 & 10 & 19.23 \\
\hline Total & 33 & 63.46 & 19 & 36.50 & 52 & 100 \\
\hline
\end{tabular}

Malignant lymphomas are relatively common in southeastern of Yemen and were considered as important public health problem among the population. It was revealed by a previous study in Yemen that it comprised approximately $16.6 \%$ of all malignant neoplasms among male cases and $8.2 \%$ among female cases [20]. In our study as showed by (Table 6) the mixed cellularity type of HL is the most common accounting $42.3 \%$ of all $\mathrm{HL}$ and lymphocyte predominance $30.7 \%$. These results are considered as higher than that reported worldwide and it may be attributed to recurrent infections Epstein Barr virus. However further studies are needed to identify other etiological factors.

Table (6): Distribution of HL according to histopathology.

\begin{tabular}{lll}
\hline Histopathology & No. & $\%$ \\
\hline Mixed cellularity & 22 & 42.3 \\
Lymphocyte predominance & 16 & 30.8 \\
Lymphocyte depletion & 11 & 21.2 \\
Nodular sclerosis & 3 & 5.8 \\
\hline Total & 52 & 100 \\
\hline
\end{tabular}

In (Table 7), the extra nodular lymphoma forming $45.3 \%$ of the NHL and mostly with gastrointestinal involvement 50, which was considered higher than the reported cases worldwide, and may be related to low level diagnostic methods for the early diagnosis of gastrointestinal diseases. It should put in consideration some diseases and habits as risk factors for malignant lymphoma. This higher frequency may be due to high prevalence of $\mathrm{H}$. pylori as it was found in some studies which show that gastric lymphoma is common in patients infected with $\mathrm{H}$. pylori and other diseases like celiac disease, dermatitis herpetiform, Crohn's diseaseand ulcerative colitis several times and this infectionprecedes the onset of lymphoma [21]. Other factors should be taken into consideration such as contact with pesticides, Epstein Barr virus, and human $\mathrm{T}$ cell leukemia virus type in addition to fertilizers use. In this study, we were stressing on the descriptive epidemiology, pathology and causes of the apparent increase of lymphoma cases among Yemeni population including recurrent infections, Epstein Barrvirus, human T cell leukemia virus, tuberculosis, abuse of pesticides, fertilizers use for cultivation of fruits and vegetables and Khat. The contacted residues of the insecticides to the skin of the farmers in addition to other socioeconomic factors which may favor the occurrence of thisneoplasm.

Table (7): Distribution of NHL according to site affected.

\begin{tabular}{lcc}
\hline Site affected & No of patients Percentage $\%$ \\
\hline Nodular lymphoma & 29 & 54.7 \\
Extra-nodular lymphoma & 24 & 45.3 \\
- Gastrointestinal & 12 & 50 \\
- Head and Neck & 7 & 29.2 \\
- Mycosis fungoides & 5 & 20.8 \\
\hline
\end{tabular}

In regard to the distribution of the disease according to the different residential areas (gover- 
norates), (Table 8), most cases were from Aden governorate $(50.4 \%)$ followed by Laheg and Abyan. $21.9 \%, 10.4 \%$ respectively. Fausto et al., disagreement with ourresult when found that, high-risk and outcomes of patients with lymphoma were from rural areas [21].

Table (8): Distribution of lymphoma according to residency.

\begin{tabular}{lcc}
\hline Governorate & No of patients & $\%$ \\
\hline Aden & 53 & 50.4 \\
Laheg & 23 & 21.9 \\
Abyan & 11 & 10.4 \\
Shabaw & 5 & 4. \\
76 & 8 & 7. \\
Hadramout & & 100 \\
Total & 105 & \\
\hline
\end{tabular}

\section{Conclusion:}

Our study was the first conducted in Aden on the pattern of malignant lymphomas NHL HL having convergent distribution, with middle age group and male gender were predominance in both types. Mixed cellularity were the most frequent compared with other types of HL, and nodular lymphoma was the most common pattern of NHL. The gastrointestinal manifestation in extra nodular lymphoma was highly prevalent. Outcomes of patients with lymphoma were from urban area.

Further studies are recommended to elucidate the relation between higher prevalence of lymphoma and exposure to various environmental factors.

\section{References}

1- BAWAZEER A.A., ABDUL-HAMIS G. and MORALES E.: Available data on cancer in southeastern Yemen. Eastern Mediterranean Health Jour., 4 (1): 107-13, 1998.

2- LINDSAY M. MORTON, SOPHIA S. WANG, WENDY COZEN, MARTHA S. LINET, et al.: Etiologic heterogeneity among non-Hodgkin lymphoma subtypes. Blood. Dec. 15, 12 (13): 5150-60, 2008.

3- ALEXANDER D., MINK P., ADAMI H.O., et al.: The non-Hodgkin lymphomas: A review of the epidemiologic literature. Int. J. Cancer, 120: 1-39, 2007.

4- GROVES F., LINET M., TRAVIS L., et al.: Cancer surveillance series: Non-Hodgkin's lymphoma incidence by histologic subtype in the United States from 1978 through 1995. J. Natl. Cancer Inst., 92: 1240-51, 2000.

5- XIONG G., ZHANG B., HUANG M.Y., ZHOU H., CHEN L. Z., FENG Q.S., et al.: Epstein-Barr virus (EBV) infection in Chinese children: A retrospective study of age-specific prevalence. PLoS One, 9 (6): 9-17, 2014.

6- ZHONG Y. and RAFNSSON: Cancer incidence among Icelandic pesticide users. International Jour. of Epidemiology, 25 (6): 1117-24, 1991.
7- West Midland regional cancer registry. Cancer and Health. West Midl and Health Authority. Public Health Report, 3: 1-10, 1995.

8- LAURENT, CAMILLE, CATHERINE M.; GOURRAUD, PIERRE-ANTOINE; De PAIVA, GEISILENE; et al.: Prevalence of Common Non-Hodgkin Lymphomas and Subtypes of Hodgkin Lymphoma by Nodal Site of Involvement. Medicine, (94): 25-87, 2015.

9- YAQO R.T., HUGHSON M.D., SULAYVANI F.K. and AL-ALLAWI N.A.: Malignant lymphoma in northern Iraq: A retrospective analysis of 270 cases according to the World Health Organization classification. Indian J. Cancer, 48: 446-51, 2011.

10- AOKI R., KARUBE K., SUGITA Y., NOMURA Y., SHIMIZU K., KIMURA Y., et al.: Distribution of malignant lymphoma in Japan: Analysis of 2260 cases, 20012006. Pathol. Int., 58: 174-82, 2008.

11- NARESH K.N., ADVANI S., ADDE M., AZIZ Z., BANAVALI S., BHATIA K., et al.: Report of an International Network of Cancer Treatment and Research workshop on non-Hodgkin's lymphoma in developing countries. Blood Cells Mol. Dis., 33: 330-7, 2004.

12- AMAL S. IBRAHIM, HUSSEIN M. KHALED, NABIEL N.H. MIKHAIL, et al.: Cancer Incidence in Egypt: Results of the National Population-Based Cancer Registry ProgramJ. Cancer Epidemiol., 2014: 437971, 2014.

13- MARIA C. DIUMENJO, GRACIELA ABRIATA, DAVID FORMAN, et al.: The burden of non-Hodgkin lymphoma in Central and South America Cancer Epidemiology, 44: 168-77, 2016.

14- SANTOSH KUMAR MONDAL, PALASH KUMAR MANDAL and TARUN KUMAR SAMANTA: Malignant lymphoma in Eastern India: A retrospective analysis of 455 cases according to World Health Organization classification. Indian J. Med. Paediatr. Oncol., 34 (4): 2426, 2013

15- MARIAM A.A. HUMAM, NAELA A. AL NAKHBI, ADNAN A. MELKAT, TOMNA M. ALMONTASER and ABDULLA S. BINNABHAN ${ }^{4}$ : Malignant lymphoma in Hadhramout Sector, Yemen: A retrospective study of 170 cases classified according to the WHO classification. Current Medical J., 1. 6-11, 2016.

16- CHANDIMA P. KARUNANAYAKE, JAMES A. DOSMAN and PUNAM PAHWA: Non-hodgkin's lymphoma and work in agriculture: Results of a two case-control studies in Saskatchewan, Canada. Indian J. Occup. Environ. Med., 17 (3): 114-21, 2013.

17- AKHTAR S., HAQUE I.U., WAFA S.M., EL-SAKA H., et al.: Malignant lymphoma in Al-Qassim, Saudi Arabia, reclassified according to the WHO classification. Saudi Medical Journal, 30 (5): 677-81, 2009.

18- CATHERINE THIEBLEMONT, SOPHIE BERNARD and THIERRY MOLINA: Management of aggressive lymphoma in very elderly patients. Hematol. Oncol., 35 ( 1): 49-53, 2017.

19- SATISH SHANBHAG AND RICHARD AMBINDER: Hodgkin Lymphoma: A review and update on recent progress. CA Cancer J. Clin., 68 (2): 116-32, 2018. 
20- BAWAZIR A.A., ABDUL-HAMID G. and MORALES E.: Available data on cancer in the south-eastern governorates of Yemen. East Mediterr Health J., 4: 107-13, 1998.

21- JEONG BAE PARK and JA SEOL KOO: Helicobacter pylori infection in gastric mucosa-associated lymphoid tissue lymphoma. World J. Gastroenterol., 20 (11): 27519, 2014.

22- FAUSTO R. LOBERIZA, Jr., ANTHONY J. CANNON J., et al.: Survival Disparities in Patients with Lymphoma According to Place of Residence and Treatment Provider: A Population-Based Study. J. Clin. Oncol., 10; 27 (32): 5376-82, 2009.

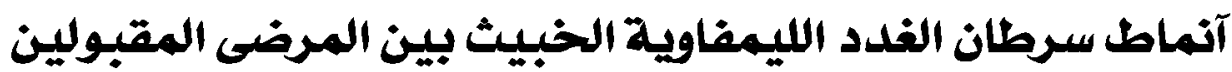

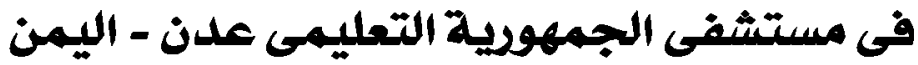

ينتشر الشرطان بشكل كبير بين سكان العالم ، آصبح تصنيف منظمة الصحة العالمية للودم الليمفاوى الخبيث شائعاً منذ تقديمه في عام

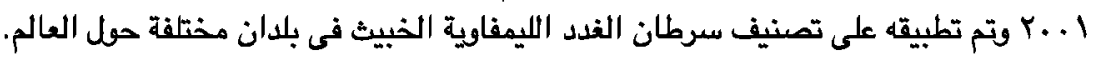

الهدف من الدراسلة:دراسة إنتشار سرطان الغدد الليمفاوية الخبيثة من بين المرضى المقبولين فى مستشفى الجمهرية التعليمى.

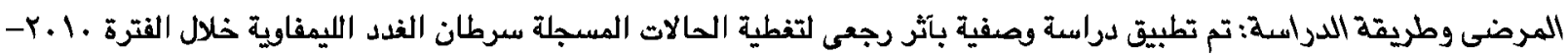

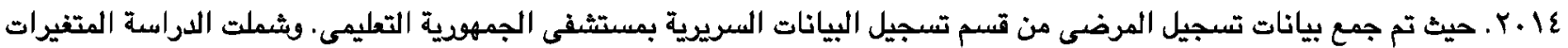

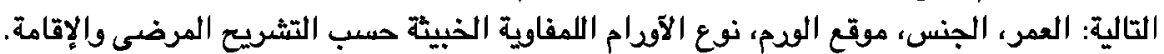

النتائج: آظهرت الدراسة آن كلا النوعين هن سرطان الغدد الليمفاوية لهما توذيع متقارب فى التساوى حيث كانت معظم الفئات العمرية

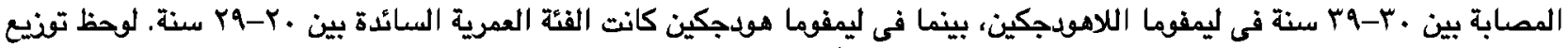

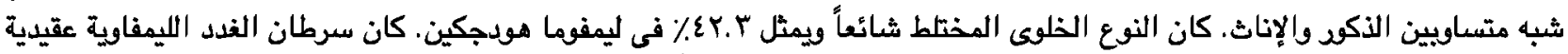

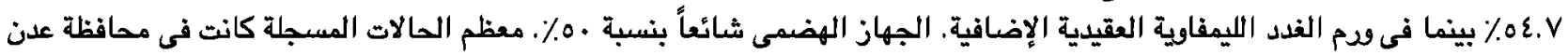
حيث يقع المستشفى.

الإستتاج: تآثر كل من الذكود والإناث بشكل متساو تقريباً، وكانت الفئة العمرية المتوبطة والخلوية المختطة هـ العـائدة فى سرطان

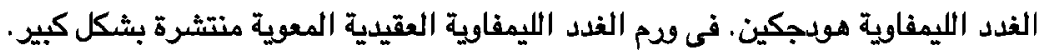

